UDC 378:334.72

JEL Classification: I23; J24; L26; C83

http://doi.org/10.21272/mmi.2019.3-19

Jelena Titko,

D.Sc., Associate Professor, EKA University of Applied Sciences, Latvia

Jekaterina Bierne,

EKA University of Applied Sciences, Latvia

\title{
COMPETENCE DEVELOPMENT OF YOUNG ENTREPRENEURS THROUGH EDUCATIONAL INNOVATIONS
}

\begin{abstract}
The questions regarding interactive methods of teaching, self-studying, active learning, as well as an implementation of a competency-based approach into study process, have been actively discussed by educational experts, authorities, scholars and teaching practitioners during the last decade. Probably, the main issue is to encourage students to participate in classroom activities and to promote successful learner-tutor cooperation. The research was aimed to evaluate the progress in entrepreneurial competencies perceived by students, participating in a specific 2-days long entrepreneurship workshop. The workshop content and schedule was designed within the framework of the international project «Strategic Partnership for Innovation and Development of Entrepreneurship». The format of the organized workshops was created during the project by the partner organizations. It is a unique teaching instrument, encouraging entrepreneurial skills and innovative spirit among students. After the workshop, the participants (students and mentors) were surveyed, using the specially designed questionnaire. One of the question blocks involved the list of competencies, which were offered for evaluation according to the criterion «progress», using 5-point scale (1 - the level stayed the same; 5 - the level really increased). The results were processed, using the methods of frequency analysis and ranking. Thus, the main goal of the paper is to reflect the results of the conducted survey in order to test the quality and success of the specific teaching method. The results indicated the substantial perceived increase in such competences, as Collaborative working, Decision making \& Problem-solving, Managing Performance, Commitment to Excellence, Speaking and Listening Skills, Presentation Skills, as well as Selfmotivation. The obvious conclusion is that such kind of interactive teaching methods is the most valuable in management teaching. However, additional peer consulting and evaluation block could be useful at the stage of the initial presentation of the business idea. The results of the research (and the idea of such workshop) can be useful for any academic staff member engaged into the study process and working with students of programmes «Entrepreneurship», «Management», «Business economics» and related ones.
\end{abstract}

Keywords: innovations in education, competences, entrepreneurship workshop, Latvia, students, survey.

Introduction. Entrepreneurship competence is one of the key competencies for life-long learning, defined by the European Council. To promote the development of the competencies, the European Commission focuses, among, others, on supporting teachers in the implementation of innovative teaching methods. (European Commission, 2017). Innovations in education and educational innovations are frequently discussed topics in academic literature. (Eckhaus, Klein, \& Kantor, 2017; Musselin, 2018; Mykhailyshyn, Kondur, \& Serman, 2018; Olorogun, Yunusa, Audu, \& Mohammed, 2018)

«Innovative» does not always mean only «technology-based». Within the current study, the authors focus on the implementation of active/problem-based/interactive/collaborative learning into the study process to discover the entrepreneurial potential of students in full. To develop students' managerial competences, re-balancing of «knowing», «doing» and «being» components in the study process is needed.

The current paper reflects the results of the survey conducted within the framework of Erasmus+ project Strategic Partnership for Innovation and Development of Entrepreneurship - SPIDE. Among others, the strategic goals of the project were «to increase practical learning and skills of the target group members [students]» and «to improve the quality and efficiency of educational best-practices at the partnering HEls».

Cite as: Titko, J., and Bierne, J. (2019). Competence Development of Young Entrepreneurs Through Educational Innovations. Marketing and Management of Innovations, 3, 255264. http://doi.org/10.21272/mmi.2019.3-19 
The goal of the current research is to evaluate the progress in entrepreneurial competencies perceived by students, participating in a specific entrepreneurship workshop, as well as to test the quality and success of the activity.

To achieve the research goal, $3^{\text {rd }}$ year students from the study programme "Management» participants of the workshop - were surveyed, using the specially designed questionnaire. Similar questions were offered to their mentors. However, the current paper reflects the results of only students' survey.

The most of students reported the increased entrepreneurial competencies after the workshop that indicates a necessity to integrate such kind of interactive teaching methods into the study process. This, in turn, points to the necessity of implementation of interactive techniques into the study process, conducting management courses.

Literature Review. Based on Musselin (2018), «competition in higher education is no longer only occurring between individuals and countries, but has become institutional, leading to a multi-level form of competition and transforming universities into competitors». Operating in a highly competitive environment, higher education institutions (HEls) should focus on their competitive advantages to take leadership positions.

New methods of teaching are among competitive advantages of HEls along with the level of digitalisation, experienced teaching staff and etc. (Dimitrova \& Dimitrova, 2017) Based on Mykhailyshin et al. (2018), «educational innovations: the content of the curriculum; new teaching technologies; high professionalism of teaching staff; organizational and methodological support of educational process» are the main factors of innovation in internal environment of un universities (Mykhailyshyn et al., 2018) One of the assessment indicators of competitiveness (Supe, Zeps, Jurgelane, \& Ribickis, 2018) is «Introduced new interdisciplinary study courses for innovative product development and entrepreneurship skills».

«New Skills Agenda for Europe» (2016) adopted by the European Commission determines new ways to achieve economic and social prosperity through the development of human capital that, in turn, requires the development of certain skills and competences of citizens. According to the Entrepreneurship 2020 Action Plan and the Rethinking Education Communication, the European Commission has emphasised the need to embed entrepreneurial learning in all sectors of education (

Entrepreneurship competence is one of the key competences for life-long learning. It is defined as «the capacity to act upon opportunities and ideas, and to transform them into values for others». This, in turn, requires «creativity, critical thinking and problem solving, taking initiative and perseverance and the ability to work collaboratively in order to plan and manage projects that are of cultural, social or financial value» (Recommendation of the European Parliament and of the Council, 2006).

In this regards, the most challenging question is «how to acquire these competencies» and the related one "how to deliver them properly»? Considering the comprehensive nature of professional competence, «modern education should focus on the student's independent activity, the organization of self-learning environments and experimental and practical training» (Yakovleva and Yakovlev, 2015). It is necessary «to increase student motivation, create a positive climate and to involve students actively in the process of learning» (Fiksl et al., 2017). The role of teachers in this process is critically important.

Entrepreneurship education is «a systematic, conscious, and goal-oriented process, through which non-entrepreneur individuals who have the necessary potential are creatively trained» (Esmi, Marzoughi, \& Torkzadeh, 2015). A successful entrepreneurship education assumes the «best match between student needs and teaching techniques» (Lee et al, 2006). Entrepreneurial competencies require «active, learnercentred pedagogies and learning activities that use practical learning opportunities from the real world» (Gautam, \& Singh, 2015). Entrepreneurship education should be based on «experiential learning styles, creative problem solving and learning by doing to arouse the interest of the students». (Jones \& Iredale, 2010) 
Two decades period after proclaimed change of paradigm for undergraduate education from teaching to learning (Barr and Tagg, 1995; Boyatzis et al., 1995) shows that teachers' applied methods are significant in creating interactive relationships between teachers and students (Jarvis, 2006; Koulaouzides, 2008). There is evidence that many universities are moving towards «the promotion of entrepreneurial soft skills such as creativity, opportunity recognition, and problem-solving abilities» (Romer-Paakkanen, \& Suonpaa, 2017)

Contemporary research on the concept of quality in management education emphasizes the following aspects: teamwork, ability to analyze different situations integrated into strategic scenarios, understanding different types of problem-solving use effective communication techniques with students, create and maintain positive learning environments in which students are actively engaged in learning social interaction, cooperative learning, and self-motivation (Carneiro, 2004).

Addressing unmet learning needs of business students could be achieved through rebalancing «knowing», «doing» and «being» components in study process in order to develop their managerial competencies more effectively (Anderson et al., 2001).

Senthamarai (2018) calls interactive teaching methods as «dynamic and communicative teaching methods», which help students to "become more engaged in learning; retain more information, thus becoming more satisfied.» Interactive teaching methods include cooperative learning methods, group discussions, debates, business simulation games, case situation analysis, and others. Applying them, a student «becomes a subject of educational activity, enters into dialogue with the teacher and other participants of the pedagogical process, and actively participates in the cognitive activities, performing creative, searching and problematic tasks». (Kutbiddinova and Eromasova, 2016) Interactive learning «helps the learner not only to easily acquire new material but to memorize it for a longer period of time.» (Giorgdze \& Dgebuadze, 2017)

The survey conducted by Wodarski et al. (2019) revealed the fact that «the most significant methods of conducting classes for shaping future competencies» are teaching by projects, problem-based learning, teamwork methods and workshops. (Wodarski et al., 2019) Based on Krpalek et al. (2018), «case study simulation methods, business simulation games and problem-solving teaching methods are important for entrepreneurship education» (Krpalek, Krelova, \& Berkova, 2018)

Methodology and research methods. The current study employed the questionnaire, developed by the partners of the project Strategic Partnership for Innovation and Development of Entrepreneurship SPIDE. Actually, two related research instruments were developed - for students and for teachers.

The questionnaire itself was designed to receive feedback of students and mentors, participating in 2days long entrepreneurship workshop. The overall aim of the workshop was to provide students with the opportunity to gain personal experience of how a business works, to understand the role it plays in providing employment and creating prosperity, and to be inspired to improve their own prospects.

For a better understanding of the nature of this survey, it is necessary to be mentioned that, actually, two workshops were organized. Many students failed to complete the tasks in the first workshop. Considering that most of the participants were 1st students, they did not have a general background and preliminary knowledge. Besides, they did not know each other to work in a team effectively. Organisational mistakes were considered and the current paper summarizes the information about the second, «improved» workshop.

Workshop's 1 st day activities involved: 1) brainstorming exercises to generate a business idea, 2) presentation of the workshop task (short business plan that should be prepared by the students), 3) working in groups or individually with the mentor assistance (idea generation, preliminary marketing research, draft of the business plan). Second-day activities were: 1) guest lecture of the business representative to inspire students for entrepreneurship, 2) presentation of the business plan, 3) evaluation of the business plan by an expert from the business environment. 
The questionnaire consisted of three blocks (Table 1).

Table 1. Structure of the questionnaire

\begin{tabular}{|c|c|c|}
\hline Block A & Questions & Description / Evaluation scale \\
\hline \multirow{3}{*}{$\begin{array}{l}\text { Respondent } \\
\text { profile }\end{array}$} & Gender & Male/ female \\
\hline & Age & Opened question \\
\hline & Working experience & Full time/ part time experience \\
\hline Block B & Questions & Description \\
\hline \multirow{4}{*}{$\begin{array}{l}\text { General } \\
\text { evaluation of the } \\
\text { workshop }\end{array}$} & $\begin{array}{l}\text { General evaluation of the workshop } \\
\text { quality }\end{array}$ & $\begin{array}{l}\text { Six statements, evaluation on 7-point scale } \\
\text { (1 - unsatisfactory; } 7 \text { - excellent) }\end{array}$ \\
\hline & Evaluation of workshop activities & $\begin{array}{l}\text { Evaluation according to the criteria: } \\
\text { Usefulness: } 1 \text { - not useful; } 5 \text { - very useful } \\
\text { Engagement: } 1 \text { - I was not engaged; } 5 \text { - I was fully engaged } \\
\text { Performance: } 1 \text { - I performed very bad; } 5 \text { - I performed very } \\
\text { well }\end{array}$ \\
\hline & Recommendation of the workshop & Evaluation on 5-point scale \\
\hline & Future participation & Evaluation on 5-point scale \\
\hline Block C & Questions & Description \\
\hline \multirow{3}{*}{$\begin{array}{l}\text { Evaluation of the } \\
\text { progress in } \\
\text { competences }\end{array}$} & $\begin{array}{l}\text { Team management \& Leadership } \\
\text { competences }\end{array}$ & \multirow{3}{*}{$\begin{array}{l}\text { Evaluation of } 15 \text { competences on } 5 \text {-point scale (1 - the level } \\
\text { stayed the same; } 5 \text { - the level really increased) }\end{array}$} \\
\hline & \begin{tabular}{|l} 
Personal development competences \\
Communication competences
\end{tabular} & \\
\hline & Research competences & \\
\hline
\end{tabular}

Sources: developed by the authors.

The main block of the questionnaire was designed to evaluate perceived progress in competencies, comparing the situation before and after the workshop. Fifteen competencies combined into four blocks were offered to the respondents (Table 2).

Table 2. Structure of block $\mathrm{C}$ of the questionnaire

\begin{tabular}{|l|l|}
\hline \multicolumn{1}{|c|}{ Groups of competences } & \multicolumn{1}{c|}{ Competence } \\
\hline \multirow{2}{*}{ Team management \& Leadership competences } & $\begin{array}{l}\text { Decision making \& Problem-solving } \\
\text { Managing performance } \\
\text { Collaborative working } \\
\text { Team building } \\
\text { Future planning } \\
\text { Persuading and influencing staff }\end{array}$ \\
\hline \multirow{2}{*}{ Personal development competences } & $\begin{array}{l}\text { Commitment to excellence } \\
\text { Mind mapping and structured thinking } \\
\text { Self-motivation }\end{array}$ \\
\hline \multirow{2}{*}{ Communication competences } & $\begin{array}{l}\text { Writing skills } \\
\text { Speaking and listening skills } \\
\text { Presentation skills }\end{array}$ \\
\hline \multirow{2}{*}{ Research competences } & $\begin{array}{l}\text { Searching for relevant information } \\
\text { Analysing information } \\
\text { Interpreting information \& Making conclusions }\end{array}$ \\
\hline
\end{tabular}

Sources: developed by the authors.

$3^{\text {rd }}$ year students of EKA University of Applied Sciences participated in the workshop within the framework of the study course «Strategic management». In total 15 students were engaged in the 
workshop activities. The requirement regarding the formation of the groups was - maximum of 3 students in one group. Thus, 5 groups were created and 5 business ideas were generated during the workshop.

Two research hypotheses were stated by the authors:

$\mathrm{H} 1$ : The most significant students' perceived progress in the development of the competencies is revealed regarding the presentation skills and collaborative working.

$\mathrm{H}$ 2: Brainstorming activities for business idea generation are evaluated by the students at the highest level according to all criteria of usefulness, engagement and performance.

Data processing was made, applying the procedures of the frequency analysis and ranking to identify the highest and the lowest level of perceived progress incompetencies. Since both students and tutors were surveyed, their answers were compared as well, but it is not reflected in the given paper.

Results. Answering the first questions students were offered to evaluate the workshop as a whole according to the several criteria, using a 7-point scale - from 1 (unsatisfactory) till 7 (excellent). Students' responses (average rating) are summarized in Fig. 1.

Participants-students evaluated the workshop very positive, especially according to the criteria «main idea» (6.47), «usefulness» (6.40) and «competence of mentors» (6.67). The lowest evaluation was given to the «communication with organizators, support provided», but the average grade was still high - 6 (maximal grade was 7 ). Only 4 students of 15 rated the workshop according to some criteria at « $3 »$ and «4».

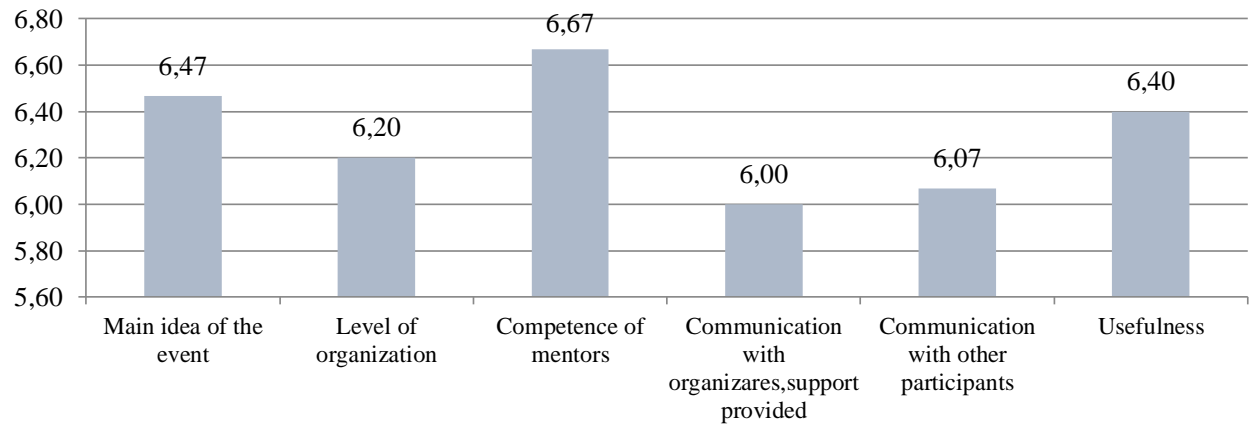

Figure 1. Students' evaluation of the workshop as a whole

Sources: calculated by the authors.

Fig. 2 presents the results of the students' evaluation of the workshop activities according to three criteria: 1) usefulness, 2) engagement, and 3) own performance. The students used 5-point scale, but the grade was different for each criterion.

The only 1 part of the whole workshop was evaluated by students negatively (mostly not useful, partial engagement, bad performance) - brainstorming activities.

Answering the question «Would you recommend participating in this event to your group mates, friends?» most of the responses (14 of 15) were «Yes, definitely». In turn, 12 of 25 participants definitely would like to participate in such kind of events in the future. 


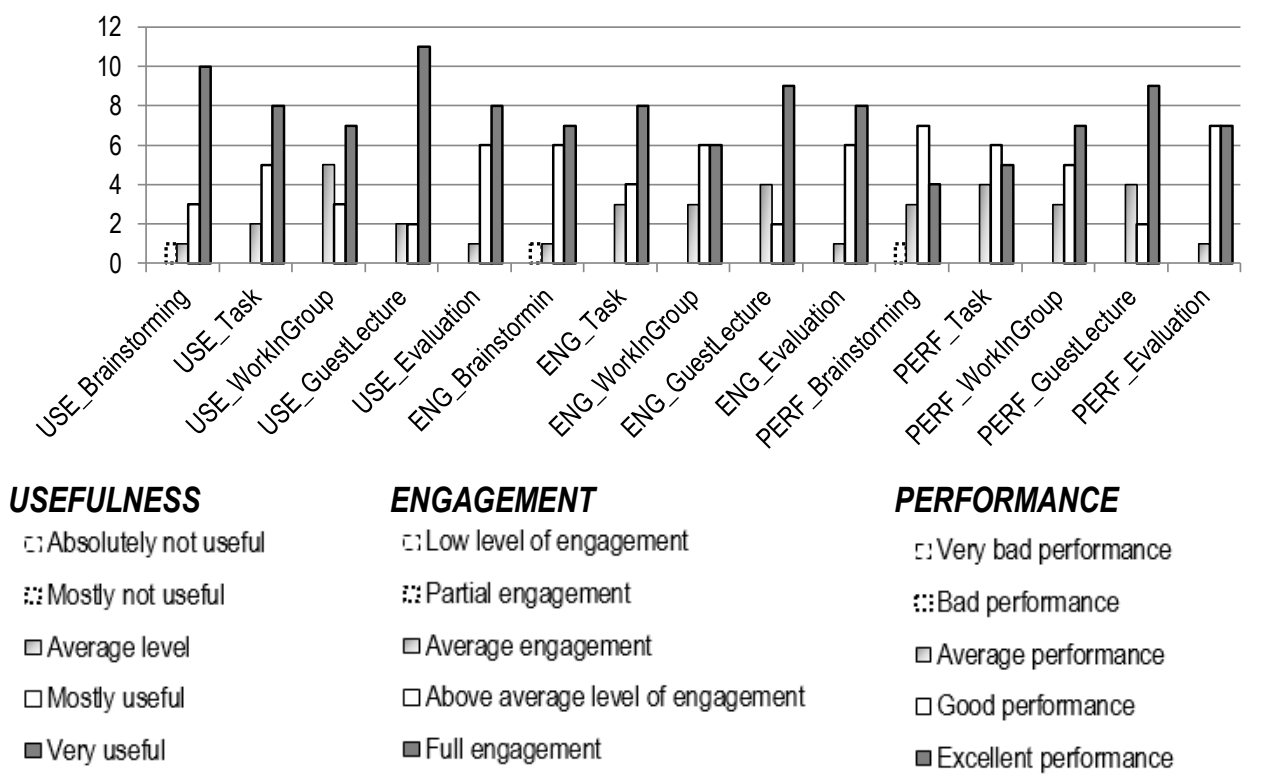

Figure 2. Students' evaluation of the workshop activities according to the criteria: usefulness, Sources: calculated by the authors. engagement and performance

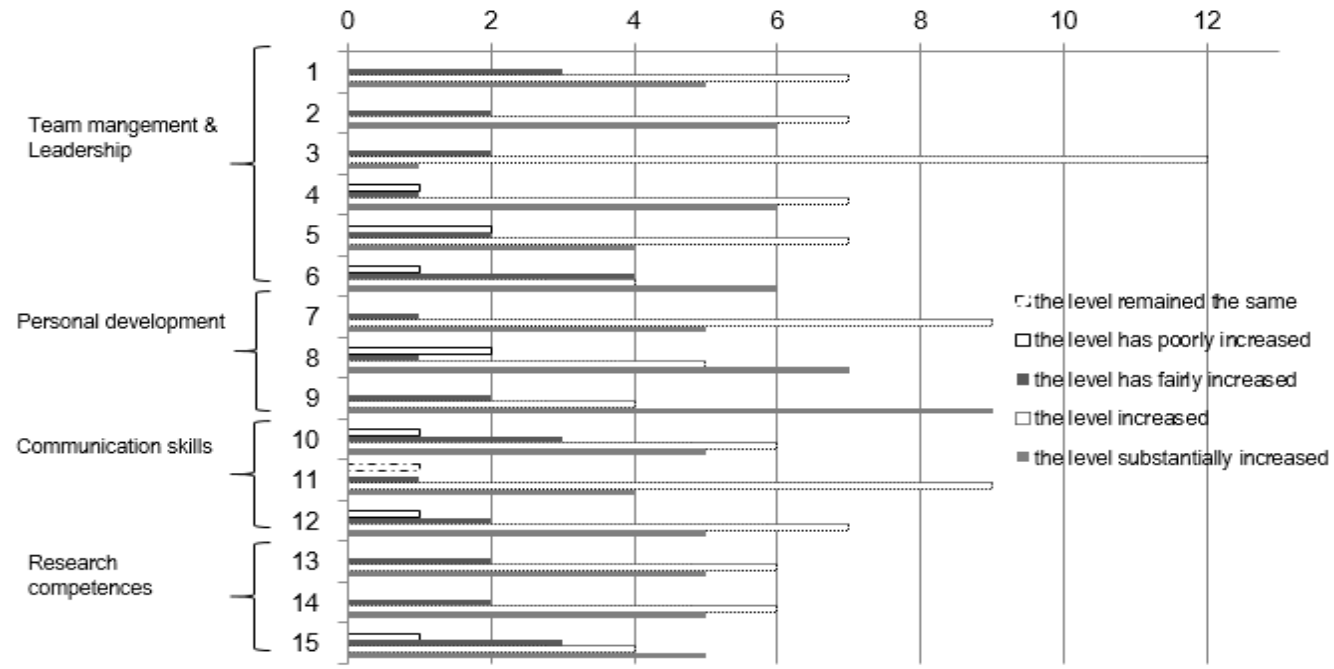

Figure 3. Students' evaluation of the progress in competence development Sources: calculated by the authors.

Answering the last question, the respondents were offered to evaluate their perceived progress in competence development after participating in ICCE workshop. The responses are summarized in Fig. 3. Each of 15 competences (Table 2) was evaluated, using the 5-point scale from «the level remained the 
same» to «the level substantially increased». The authors did not assume the possibility that the level can decrease after participating in the workshop.

Most of students pointed to the fact that their competence «Collaborative working» has been increased after the workshop, as well as the competencies «Decision making \& Problem solving», «Managing Performance», "Commitment to Excellence», «Speaking and Listening Skills» and «Presentation Skills». «Self-motivation» increased substantially on the viewpoint of many students. Very few answers were «the level remained the same» or «the level has poorly increased».

Besides, Table 3 summarizes the competencies within each of five groups, the level of which was substantially increased from the viewpoint of most students.

Table 3. Competencies with the highest perceived progress

\begin{tabular}{|l|l|}
\hline \multicolumn{1}{|c|}{ Group of competencies } & \multicolumn{1}{c|}{ Competence with the highest perceived progress } \\
\hline Team management \& Leadership competences & Managing performance \\
\hline Personal development competences & Self-motivation \\
\hline Communication competences & Presentation skills \\
\hline Research competences & Searching for relevant information; Analysing information \\
\hline
\end{tabular}

Recommendations after the first workshop included the suggestion to engage elder students into the activities and to limit the team to maximum 5 students. Since the recommendations were considered, organizing the second workshop, there were no problems with students' discipline, i.e., the number of participants was not changed between the $1^{\text {st }}$ and the $2^{\text {nd }}$ day, and all the groups finished their tasks.

As one of the predictable issues was that developing English version of business plan was equally challenging for students as developing the plan itself. However, this problem will not arise, when such kind of workshops will be organized outside the project framework.

Conclusions. The overall conclusion from the survey is that such kind of interactive techniques, as a described workshop, is a very successful way how to increase students' entrepreneurial competencies. Management education should be organized, implementing «learning-by-doing» practices and enforcing students' engagement into study process.

Regarding the particular workshop, developed and conducted at EKA University of Applied Sciences, several shortcomings were detected after the first round: (1) they completely failed in marketing research and forecasting of business activities, (2) they did not have a general background and preliminary knowledge to complete the tasks properly, and (3) they did not know each other to work in team effectively. However, even during the first attempt the students managed to generate ideas and some of them were quite good in oral presentation. Besides, the positive fact was that the students acquired awareness about business plan structure problems entrepreneurs should solve.

Considering the mentors' recommendations on improvements of the workshop organization, there were no problems with students' discipline, i.e., the number of participants was not changed between the 1 st and the $2^{\text {nd }}$ day, and all the groups finished their tasks. Additional recommendations were made:

- Additional peer consulting and evaluation block could be useful at the stage of initial presentation of the business idea

- Considering that performing of workshop tasks requires from students sufficient background, the workshop is recommended to be longer - at least three days instead of two.

As for outcomes from the workshop, most of students pointed to the fact that their competence «Collaborative working» has been increased after the workshop, as well as the competencies «Decision making \& Problem solving», «Managing Performance», "Commitment to Excellence», «Speaking and Listening Skills» and «Presentation Skills». Almost all students would definitely recommend participating 
in this event to their group mates/friends, as well as definitely would like to participate in such kind of events in the future.

The results of the testing of the stated hypotheses:

$\mathrm{H} 1$ : The most significant students' perceived progress in the development of the competencies is revealed regarding the presentation skills and collaborative working. Partially confirmed.

Competencies «Collaborative working» and «Presentation skills» improved from the viewpoint of students, but there was also a significant perceived progress in several other competencies, such as «Commitment to excellence», «Managing performance», «Team building» and others.

$\mathrm{H} 2$ : Brainstorming activities for business idea generation are evaluated by the students at the highest level according to the all criteria of usefulness, engagement and performance. Confirmed.

Brainstorming activities were evaluated were positively. The lowest evaluation received the activity «Working in groups or individually with the mentor assistance». It means that improvements are still needed. However, such kind of activities is a great experience for both students and lecturers, and it is important to organize them regularly. This, in turn, could be achieved by changes of study curriculum and including such events as an integral part of study programme.

The current study is limited by the number of students participated in workshops, and also the results reflect the viewpoints of the representatives from one institution. However, the reliability of the results can be confirmed by the reports prepared in other organizations - SPIDE project participants. The similar kind of activities were organized in the Integrated Business Institute from Skopje 9Macedonia) and in the Faculty of Administration, University of Ljubljana (Slovenia). Based on the feedback from students, professors and business experts and including our detailed analysis of both workshops at each partner, it was concluded that ICCE activities in general have yielded positive results. Students managed to develop skills and knowledge necessary to develop a business plan, improve their leadership and team management skills, communication skills and research competencies.

Author Contributions: Conceptualization, J. T. and J. B.; investigation - J. B.; methodology, J. T. and J. B.; data processing, J. T.; writing - all stages, J. T.

Funding: This research was conducted within the framework of the project «Strategic Partnership for Innovation and Development of Entrepreneurship - SPIDE» that was supported and financed by the European Commission, Erasmus+ Programme, Key Action 2 - Strategic Partnership (grant agreement No. 2016-1-MK01-KA203-021666).

The European Commission support for the production of this publication does not constitute endorsement of the contents which reflects the views only of the authors, and the Commission cannot be held responsible for any use which may be made of the information contained therein.

\section{References}

Anderson, L. W., Krathwohl, D. R., and Bloom, B. S. (2001). A taxonomy for learning, teaching, and assessing: A revision of Bloom's taxonomy of educational objectives. Allyn \& Bacon.

Barr, R. B., and Tagg, J. (1995). From teaching to learning - A new paradigm for undergraduate education. The magazine of higher learning, 27(6), $12-26$.

Boyatzis, R. E., Cowen, S. S., and Kolb, D. A. (1995). Innovation in professional education: Steps on a journey from teaching to learning: The story of change and invention at the Weatherhead School of Management. Jossey-Bass.

Carneiro, A. (2004). Teaching management and management educators: some considerations. Management Decision, 42(3/4), 430-438.

Dimitrova, G., \& Dimitrova, T. (2017). Competitiveness of the universities: measurement capabilities. Trakia Journal of Science, 15(Suppl.1), 311-316. https://doi.org/10.15547/tjs.2017.s.01.055

Eckhaus, E., Klein, G., \& Kantor, J. (2017). Experiential Learning in Management Education. Business, Management and Education, 15(1), 42-56. https://doi.org/10.3846/bme.2017.345 
Esmi, K., Marzoughi, R., \& Torkzadeh, J. (2015). Teaching learning methods of an entrepreneurship curriculum. Journal of advances in medical education \& professionalism, 3(4), 172-177.

European Commission (2017). Developing Key Competencies for All throughout Life. Available: https://ec.europa.eu/education/sites/education/files/document-library-docs/factsheet-key-competences-lifelong-learning_en.pdf

Fiksl, M., Flogie, A., \& Abersek, B. (2017). Innovative teaching/learning methods to improve science, technology and engineering classroom climate and interest. Journal of Baltic Science Education, 16(6), 1009-1019.

Gautam, M. K., \& Singh, S. K. (2015). Entrepreneurship education: concept, characteristics and implications for teacher education. An International Journal of Education, 5(1), 21-35.

Gentry, J. W., McCain, K. C., \& Burns, A. C. (1979). Relating teaching methods with educational objectives in the business curriculum. Insights into Experiential Pedagogy, 6, 196-198.

Giorgdze, M., \& Dgebuadze, M. (2017). INTERACTIVE TEACHING METHODS: CHALLENGES AND PERSPECTIVES. IJAEDU - International E-Journal of Advances in Education, 544-548. https://doi.org/10.18768/ijaedu.370419

Jarvis, P. (Ed.). (2006). The theory and practice of teaching. Routledge.

Jones, B., \& Iredale, N. (2010). Enterprise education as pedagogy. Education + Training, 52(1), 7-19. https://doi.org/10.1108/00400911011017654

Koulaouzides, G. (2008). Transformative learning: A learning theory for adult education. Pedagogical Review, 46, 21-32.

Krpalek, P., Krelova, K. K., \& Berkova, K. (2018). Entrepreneurship in relation to contemporary concepts of education (language - english). Marketing and Management of Innovations, (2), 11-22. https://doi.org/10.21272/mmi.2018.2-01

Kutbiddinova, R. A., \& Eromasova, A. (2016). The Use of Interactive Methods in the Educational Process of the Higher Education Institution. International Journal of Environmental and Science Education, 11(14), 6557-6572.

Lee, S. M., Lim, S. B., Pathak, R. D., Chang, D., \& Li, W. (2006). Influences on students attitudes toward entrepreneurship: a multi-country study. The International Entrepreneurship and Management Journal, 2(3), 351-366.

Musselin, C. (2018). New forms of competition in higher education1. Socio-Economic Review, 16(3), 657-683. https://doi.org/10.1093/ser/mwy033

Mykhailyshyn, H., Kondur, O., \& Serman, L. (2018). Innovation of Education and Educational Innovations in Conditions of Modern Higher Education Institution. Journal of Vasyl Stefanyk Precarpathian National University, 5(1). https://doi.org/10.15330/jpnu.5.1.9-16

New Skills Agenda for Europe (2016). Available: https://eur-lex.europa.eu/legal-content/EN/TXT/?uri=CELEX:52016DC0381

Olorogun, L., Yunusa, N., Audu, H. G., \& Mohammed, A. A. (2018). Management of educational innovations: effects of infusing «critical thinking» into Islamic finance curricula. Marketing and Management of Innovations, (2), 69-78. https://doi.org/10.21272/mmi.2018.2-06

RECOMMENDATION OF THE EUROPEAN PARLIAMENT AND OF THE COUNCIL of 18 December 2006 on key competences for lifelong learning. Available: https://eur-lex.europa.eu/legal-content/EN/TXT/PDF/?uri=CELEX:32006H0962\&from=EN

Romer-Paakkanen, T., \& Suonpaa, M. (2017). Multiple Objectives and Means of Entrepreneurship Education. Haaga-Helia University of Applied Sciences. Available: https://shop. haaga-helia.com/WebRoot/HaagaHelia/Shops/Haaga/MediaGallery/Multiple_ Objectives_and_Means_of_Entrepreneurship_at_Finnish_Universities_of_Applied_Sciences.pdf

Senthamarai, S. (2018). Interactive teaching strategies. Journal of Applied and Advanced Research, 3(1), S36-S38.

Supe, L., Zeps, A., Jurgelane, I., \& Ribickis, L. (2018, December 10). Factors affecting the competitiveness of a higher education institution: systematic literature overview. 245-251. https://doi.org/10.22616/rrd.24.2018.079

Wodarski, K., Machnik-Slomka, J., \& Semrau, J. (2019). Students' Competencies for the Future and Innovativeness - Research Among Managerial Staff of Public Universities of Technology in Poland. Marketing and Management of Innovations, 2, 198-205. http://doi.org/10.21272/mmi.2019.2-17

Yakovleva, N. O., \& Yakovlev, E. V. (2014). Interactive teaching methods in contemporary higher education. Pacific Science Review, 16(2), 75-80.

Єлена Тітко, D.SC., Університет прикладних наук ЕКА (Латвія);

Єкатерина Бьорне, Університет прикладних наук ЕКА (Латвія).

Роль освітніх інновацій у розвитку компетенцій молодих підприємців

Протягом останнього десятиліття експерти у срері освіти, органи влади, вчені та викладачі приділяють особливий інтерес до обговорення питань щодо напрямів впровадження інноваційних та інтерактивних методів навчання, самоосвіти, активного навчання в освітній процес. Авторами наголошено, що головним викликом сучасного освітнього процесу є залучення студентів до аудиторних занять та налагодження дієвої комунікації між лектором та студентами. Головною метою дослідження є визначення якості та ефективності методів навчання у ході проведення тренінгів для молоді. У статті здійснено оиінювання компетенцій, набутих студентами, у результаті участі у дводенному тренінгу з підприємниитва. Авторами зазначено, що зміст та розклад тренінгу розроблено у рамках міжнародного проекту «Стратегічне партнерство для інновацій та розвитку підприємництва». При цьому формат проведення тренінгу сформовано на основні рекомендацій наданих партнерськими організаціями (представники малого 
та середнього бізнесу) у ході реалізації проекту. Використаний формат тренінгу є унікальним інструментом навчання, який заохочує розвиток підприємницьких навичок та зароджує інноваційних дух серед студентів. Основною ідеєю та завданням тренінгу було генерація та презентація бізнес-ідеї та особливості ії реалізації. 3 метою виявлення рівня корисності тренінгу для його учасників (студентів та менторів) було проведено анкетування. У структурі даної анкети одна із секцій включала перелік компетенцій, які було запропоновано оцінити за 5-ти бальною щкалою (1 - рівень компетенцій залишився незмінним; 5 - рівень компетенцій значно покращився). Для аналізу результатів опитування використано методи частотного аналізу та ранжування. Отримані дані свідчать про суттєве сприйняття учасників тренінгу таких компетенцій як: спільна робота; прийняття рішень та вирішення проблем; управління результативністю; прагнення досконалості; навички слухання та комунікації; вміння подавати матеріал; самомотивація. Авторами зазначено, що подібні методи інноваційного та інтерактивного навчання є більш ефективними, аніж традиційні. Наголошено, що додаткові консультації та оцінювання експертами повинно відбуватись на перших етапах командної роботи при розробиі бізнес-ідеї. Отримані результати дослідження мають практичне значення $і$ можуть бути корисними для науково-педагогічних працівників, залучених у навчальний процес та роботу зі студентами за програмами «Підприємниитво», «Менеджмент», «Економіка підприємства» та іншими суміжними за галузями знань програмами.

Ключові слова: інновації в освіті, компетентності, семінари з підприємництва, Латвія, студенти, дослідження.

Manuscript received: 18.08 .2019

(c) The author(s) 2019. This article is published with open access at Sumy State University. 